\title{
Relationship between the Taxpaying Benefits Satisfaction and the Business Performance of Sole Proprietors in Nagcarlan Central Business District
}

\author{
Rexibal B. Plata, Jr., Elymar A. Pascual \\ rexibalplatajr.@gmail.com \\ Department of Education, Nagcarlan, Laguna, Philippines, 4002
}

\begin{abstract}
Nowadays, many projects by the Philippine government have been implemented in our society to provide benefits for all Filipinos. These became possible because of taxation, and one of the major taxpayers are sole proprietors. These business owners also experience the advantages that satisfy them in exchange for the taxes they pay. What's interesting to know is that if the increase or decrease of satisfaction rate corresponds toan increase or decrease in the business performance of sole proprietorships. That's why this study focused on determining the relationship between taxpaying benefits satisfaction and the performance of sole proprietors in Nagcarlan Central Business District. This study is a non-experimental quantitative research and the approach is descriptive correlational design. The sampling technique that was used was purposive sampling wherein the researcher chose 20 sole proprietors from Nagcarlan Central Business District. A surveyquestionnaire was used to collect data from the respondents that includes questions set on a 5-point Likert scale. It was found out that the taxpaying benefits satisfaction obtained a mean level of 3.66 while the business performance gained 4.09.Using Pearson-r, the p-value that the researcher got was 0.87 , which is greater than the alpha level of 0.05 . This means that there is no significant relationship between the taxpaying benefits satisfaction and the business performance of sole proprietors in Nagcarlan Central Business District. The recommendation for the government is to still be consistent in providing the necessary benefits to its stakeholders especially to sole proprietors and conduct a seminar for business owners regarding taxpaying benefits. For sole proprietors, they should still perform well in their respective businesses and always pay their taxes properly. The recommendation for future researchers is to conduct studies that are relevant to the topic of this and also use this research to support their works.
\end{abstract}

Keywords: tax; taxpaying; benefit; satisfaction; business; performance; sole proprietor

\section{Introduction}

Benjamin Franklin once said, "In this world, nothing can be said to be certain except death and taxes." This just means that aside fromdeath, paying of tax is also inescapable. Tax is considered the "lifeblood" of the government. It serves as their financial resources for them to be able to sustain their activities and raise funds for their projects aimed for the benefit of the society. These resources come mostly from the people that are paying the taxes according to their income, the value of their property, etc. Without taxation, the government might not function well and might fail to provide the necessary needs of its stakeholders. That's why compliance of people to taxation is a must to enable the government to ensure an orderly and harmonious life in the society.

Given that the taxpayers are given the responsibility to conform to their role in our economy, the government also has the obligation to 
provide the benefits that are expected by the people to take place in the community in return for the taxes they are paying. If these benefits will be effectively granted and will satisfy the growing demand in the community, not only taxpayers but all people will be helped. In Nagcarlan, Laguna, the center of business industry is called Nagcarlan Central Business District. Located here are the public market and other businesses that are mostly sole proprietorships. They also play a vital role because they are one of the contributors of revenues in Nagcarlan, making our town a $2^{\text {nd }}$ municipal income class as of 2016. Meanwhile, the projects by the government in our community that are notable are the public works and highways development, protection and assistance programs, free medical check-ups in public hospitals, and accessible public education for all. These made a lot of contributions in the living of Nagcarlangins, especiallyto sole proprietors in Nagcarlan Central Business District who are one of the main sources of funds by the government. In the view of the fact that the aforementioned projects are conducted by the government to help its stakeholders, it is interesting to know if these satisfy the expectations of sole proprietors and if these can be a source of inspiration for them be able to enhance more their businesses' financial position, customer satisfaction, market competitiveness, and motivation to operate well. To do so, the researcher intends to determine if the taxpaying benefits satisfy the sole proprietors in Nagcarlan Central Business District thus causing them to perform well in their own businesses.

With all this useful benefits given by the authority, sole proprietors might become more inspired to perform well in their own businesses. One might be more optimistic to invest larger capital for his/her firm and one might be more excited to unleash his/her business' full potential for it to generate lots of income. Who knows, this possibilities might be one of thesolutions to solve poverty in our society and to upgrade the level of our economy.

\subsection{Background of the Study}

It was in the year 2015 when the government started a road widening project in Nagcarlan, Laguna. As of now, it is not yet finished but the enhancement of the majority of public roads in our town had been successful. Although many families were affected by this project because some parts of their houses that are very near to these roads were demolished, the government fixed their homes after the road near them was widened. This project was conducted by Department of Public Works and Highways (DPWH), and the fund they used to execute this came mainly from the taxes paid by taxpayers in our country. Furthermore, numerous public schools have been established in Nagcarlan that grant people an opportunity to study without being financially challenged. It is because our government is the one who sustains these institutions with funds that came also from taxation. This means that taxpayers in Nagcarlan contributed a lot of help for the development of our own town, and one of those contributors is the sole proprietors in Nagcarlan Central Business District. The profits generated by sole proprietorships have a pivotal role in our economy because the more they earn, the more help they can give to the government in order to finance their projects. That's why it is important and also interesting to know that if the more benefits from the government such as road widening, free education and many more satisfy the sole proprietors, the more motivated they might be to perform well in their own businesses in Nagcarlan Central Business District.

\subsection{Statement of the Problem}

This study aimed to determine the relationship between the taxpaying benefits satisfaction and the business performance of sole proprietors in Nagcarlan Central Business District.

Specifically, this intends to answer the following questions:

- What is the mean level of the taxpaying benefits satisfaction?

- What is the mean level of the business performance? 
- Is there a significant relationship between the taxpaying benefits satisfaction and the business performance of sole proprietors in Nagcarlan Central Business District?

\subsection{Significance of the Study}

Sole Proprietors will be benefited primarily by this study because the results will inform them about the relationship between the taxpaying benefits satisfaction and the business performance of sole proprietors in Nagcarlan Central Business District. This will also help them to know if they feel satisfaction with the benefits that they are experiencing now in return for the taxes they are paying or the government still lack in fulfillingits stakeholders' prospective advantages.

Future Sole Proprietors will be benefited by the results of this research that will surely guide them in the business they aspire to establish. It is because they will be well-informed on how the current sole proprietors in Nagcarlan Central Business District are being satisfied or not by the projects of the government in our town and what to focus on in their planned business based on the performance of these sole proprietorships that are already established in the business industry.

Government will also acquire essential knowledge in the findings of this study that will be helpful for them to determine if the benefits they are providing in our town satisfies taxpayers especially sole proprietors in Nagcarlan Central Business District and motivates them to operate well their respective businesses. Once ascertained, they might plan to provide more projects in Nagcarlan if sole proprietors are achieving satisfaction from the benefits and performing effectively in their businesses or resolve deficiencies in the benefits they give if ever there are.

Future Researchers will gain an advantage from the findings of this study for it will help them to be knowledgeable about the relationship between the taxpaying benefits satisfaction and the business performanceof sole proprietors in Nagcarlan Central Business District. It would help them to be better analysts and it can serve as a reference guide formore studies related to this topic in the future.

\subsection{Scope and Limitation}

This study focused on identifying the relationship between thetaxpaying benefits satisfaction and the business performance of sole proprietors in Nagcarlan Central Business District. The location of thisstudy will be in Nagcarlan, Laguna and will be conducted in the first semester of this school year 2021 - 2022. The respondents will be the owners of various sole proprietorships established in Nagcarlan Central Business District which is the center of business industry in our town and the location of the public market and other kinds of businesses.

\subsection{Theoretical Framework}

Benefit theory was developed originally by two economists of the Stockholm School, namely Knut Wicksell (1896) and Erik Lindahl (1919). This theory states that the country should impose taxes on people in accordance to the benefit bestowed on them. The more benefits an individual obtains from the nation's activities, the more he/she should payto the government. 


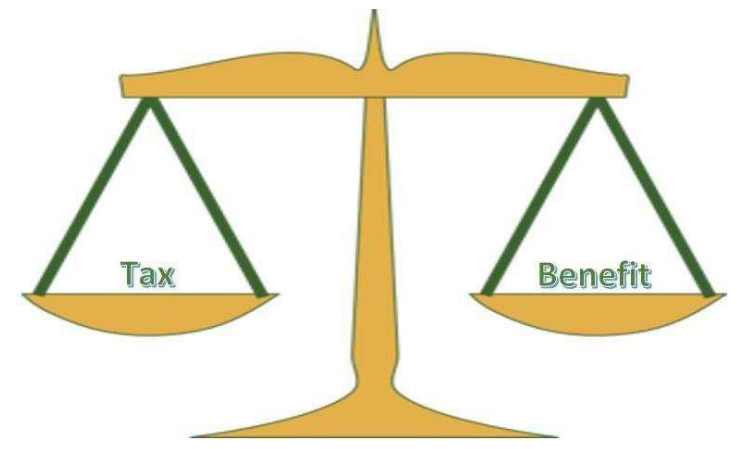

Figure 1. Wicksell and Lindahl's Benefit Theory Model

In this study, the benefit theory will be used to determine if the benefits from the government that are experiencing by the people of our town give satisfaction on sole proprietors in Nagcarlan Central Business District in exchange for the taxes they are paying, and if their satisfaction level can make an impact to their performance in their own businesses. Also, this theory will be used to support the results to be discovered and assertions to be constructed in the conclusion part of this research.

\subsection{Conceptual Framework}

The figure below shows the framework of the current study that is presented in the form of a research paradigm. The independent variable contains the taxpaying benefits while the dependent variable contains the performance of sole proprietorships.

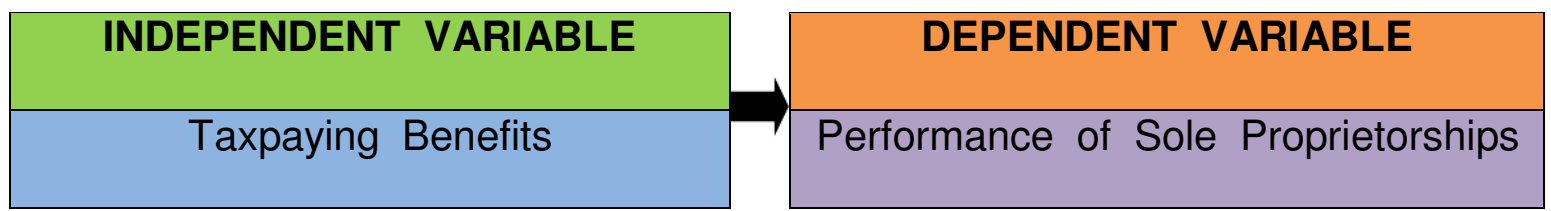

Figure 2. Research Paradigm

\subsection{Hypothesis}

The tentative solution for this study is:

There is no significant relationship between the taxpaying benefits satisfaction and the business performance of sole proprietors in Nagcarlan Central Business District.

\subsection{Definition of Terms}

Satisfaction - According to Merriam-Webster Dictionary, satisfaction is a happy or pleased feeling because of something that you did orsomething that happened to you. In this study, it will be used to ascertain whether sole proprietors experience this kind of feeling when they and our town receive the benefits from the government.It will be measured with the help of survey questions.

Performance - According to Merriam-Webster Dictionary, performance is the act of doing a job, an activity, etc. In this research, it will be used to identify if the businesses of sole proprietors in Nagcarlan Central Business District are in a high or low level of performance in 
the industry. It will be measured with the aid of survey questions.

Benefit - According to Merriam-Webster Dictionary, benefit is something that provides happiness or does good for a person or thing. In this study, it will be used to know if sole proprietors receive the appropriate benefits they expect in return for the taxes they pay to the government.

\section{Review of Related Literature}

This chapter presents the studies and literature that are related to the topic of this research.

According to Ganeshasundaram Raguragavan (2001), the increasing interest of academics and practitioners towards the market research evaluation has been present nowadays. A logical connection between helpful information and decent decisions is being highlighted by the discourse about the relationship between market research and the performance of business. This study that was accomplished opposes the idea of several market people that there is a positive relationship between the market research and business performance because various kinds of market research have diverse effects on business performance.

A study from Siti Nur 'Atikah Zulkiffli and Nelson Perera (2011) concludes that according to Dess and Robinson (1984), approximating the business performance precisely is tough when using mailed questionnaires specifically because the data will be prone to errors while measuring due to the its variance and confidentiality in accounting processes among joining companies.

Jung-in Bae (2006) found out in his research that there is a significant relationship between the benefit satisfaction and the intention to leave from a company. The respondents, who were at the age of 44 and younger and who were not either married or living with partners were more probable to depart. Moreover, male respondents have experienced more satisfaction with the benefits they are receiving than females.

According to the conclusion of the research conducted by Yi-Chen Lin, Magnolia Yulan Hsing, and Yi-Chuan Wang (2008), next to the use of collaborative design is innovative transformations in business operation and enhancement in the performance of the business kindle a lively communication between the business and its associate firms. The product design's time, R\&D and production is reduced for the products to be able to appear in the market and grab opportunities as soon as possible.

The federal and state laws with regards to a sole proprietorship's taxation may establish an advantage in some instances. The law says that all business revenue or loss will be considered as individual revenue or loss and taxed appropriately. The sole proprietor asserts the businessrevenue on an individual tax return's separate timetable. When the total income is calculated, application of individual income tax rates will take place. If it's a small business and the proprietor has a small amount of income from other sources, the individual tax rates as pertained to revenue from a sole proprietorship may be substantially lesser than corporate tax rates. Likewise, if the business runs at a loss, the loss will be directed to balance other functioning personal revenue of the sole proprietor thus resulting in direct tax funds. (Sheldon V. Vermonty,1999).

According to Noor Suhaila Shaharuddin (2012), tax compliance problems have been studied amid researchers since 1960. There were different factors affecting the compliance behavior of a person based on an analysis regarding the tax compliance. Nevertheless, the bulk of these researches concentrated on the compliance behavior of individual income taxpayers in some countries. For business taxpayers from small businesses and partnerships, only small amount of information are known about their compliance level. A report discovered that small business groups like eateries or those who manage their business beside streets orat vendors' market do not to completely abide by with the tax laws. These concerns became more important for some business taxpayers with the application of Self-Assessment System (SAS). In this system, they are not only necessitated to obey to their tax responsibilities of performing business, but taxpayers must also have adequate tax information in their minds for them to be able to properly evaluate their tax liability and to organize tax return forms on 
the dot.

The tax has an important part in the development of Small and Medium Enterprises (SMEs). The part of SMEs in Tanzania is vital in boosting the socio-economic growth program of the nation more thus the arrangement of the tax-system to the environment-specific SME growth demands can be deemed an essential scheme for the policy creators. Concentrating in this matter, the research aspired to discover the managers/executive officers' perspective of managers or executive regarding the effectiveness of tax-system in endorsing SMEs development in the nation. After discovering the results of this study, it show that most of the respondents understand the opposing effect of current rules on the development of SMEs and recommend for the tax rules in the nation to be restructured. (Mika Mungaya, Andrew H. Mbwambo, Shiv K. Triphati, 2012)

This study examines the effects to the economy of various income splitting guidelines for sole proprietorships/partnerships and corporations ina dual income tax scheme. We infer that the tax guidelines for closely held corporations propose unevenly the same amount of capital as for widely held corporations. Meanwhile, sole proprietorships'/partnerships' amount of capital is lesser than corporate companies' because the income-splitting guidelines both counteract the impact of the high labor income taxand evade the two-tier taxation on the corporate structure of organization. (Tobias Lindhe, Jan Södersten, and Ann Öberg, 2003)

In the research conducted by Evans Tee, Lawrence Asare Boadi, and Richard Takyi Opoku (2016), the primary conclusion is that taxes charged on small and medium businesses influence their development in terms of incomes in various methods. It has been discovered that adjustments in tax rates lead to the adjustment in prices of differentgoods and services. Increase in tax rates directs to better manufacture, dissemination and selling expenses is what the outcomes depict which lead to higher prices thus causing consumers to change their purchasing manner. Fewer buying of the product became the response of people to the higher prices. That's why some manufacturers reduce the production and the number of workers when sales decrease.

According to the study of William G. Gale and Andrew A. Samwick (2014), an impact to economic movement can be caused by both changesin the level of profits and changes in the tax system formation, but not all tax adjustments have corresponding and positive outcomes on long-term development. The claim that income tax downgrades the growth is frequently reiterated that it is at times considered as gospel. Nevertheless, an unusual and more complex tale is being narrated by theory, proof, andsimulation researches. The possibility to increase economic developments by enhancing incentives to work, save, and invest is what tax cuts propose. However, they likewise make profit effects that diminish the demand to involve in productive economic movement, and they may subsidize old capital, which provides bonus rewards to asset owners who weaken incentives for new activity.

Tax compliance puts a big problem on small enterprises, both in the collective and comparative to large businesses. Enterprises with lower than $\$ 1$ million in profit abide almost two-thirds of business compliance expenditures based on the approximation of Internal Revenue Service (IRS), and that those expenditures are greater for small businesses than for big ones. Underpaying of small enterprises to their taxes is more probable to simultaneously happen. Small businesses can also minimize their profits and exaggerate their expenditures hence underpaying their taxes since they frequently involve in cash transactions that are not conveyed to the IRS. Some underpayments are unintentional, revealing thestruggle of obeying with our complex tax code, and some are intentional. High compliance charges hinder responsible small businesses, while the better opportunity to underpay taxes favors less responsible ones. (Donald B. Marron, 2014)

According to the study of Talam Cynthia Jepkogei (2014), small andmedium enterprises portray a pivotal role in growth of the economy of Kenya. The significance of their sector in the economic growth of any nation in recent years cannot be undervalued especially with regard to formation of employment, innovation, enriching the normal living of people and financial help to the development of Kenya's GDP. This area's development is delayed by various hindrances such as lack of financial properties to increase the entrepreneur managerial skills, amateurish worker, creation of low quality 
products, products marketing deficiency, infrastructure and above-all taxation rule which does not support their possible development. The study discovered that there was a significant correlation between taxation and small enterprises' summary of sector growth. The recommendation of this research is to have friendly tax policy for all rookie enterprises preferably a tax holiday, or an introduction of a growth limit which can be said to be a level stable, sufficient to maintain tax payment.

\section{Research Methodology}

This chapter contains the research design, population and sampling technique, data gathering procedure, data gathering instrument, and statistical tools.

\subsection{Research Design}

This study is a non-experimental quantitative research. The approach that will be used is descriptive correlational design wherein the variables will be described first and then the relationship between them will be analyzed. According to Siddharth Kalla (2011), "Correlational study determines whether or not two variables are correlated; this means to study whether an increase or decrease in one variable corresponds to an increase or decrease in the other variable."

\subsection{Population and Sampling Technique}

The sampling technique that will be used is purposive sampling wherein the researcher will choose 20 sole proprietors from Nagcarlan Central Business District who will be the respondents of this study.

\subsection{Data Gathering Procedure}

The flowchart below illustrates the steps conducted to collect datafrom the respondents in this research:

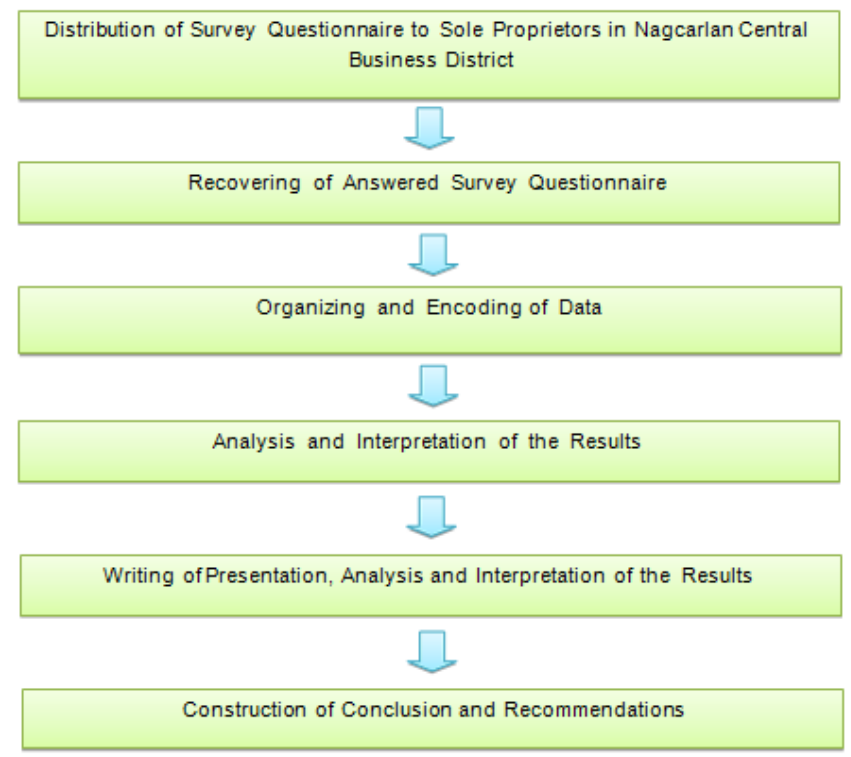

Figure 3. Research Procedure 


\title{
3.4. Data Gathering Instrument
}

A survey questionnaire is used to collect data from the respondents that include questions set on a 5-point Likert scale regarding the relationship between the taxpaying benefits satisfaction and theperformance of their sole proprietors in Nagcarlan Central Business District. This method is selected for the researcher to be able to collect adequate information that are needed to determine an accurate estimate of the relationship between the variables.

The rating scale of the survey questionnaire can be seen below:

Rating
5
4
3
2
1

\author{
Description \\ Strongly Agree \\ Agree \\ Neutral \\ Disagree \\ Strongly Disagree
}

\subsection{Statistical Tools}

The statistical tools that would help in answering the specific questions mentioned at the beginning of the study are as follows:

SOP \#1 - mean and standard deviation

SOP \#2 - mean and standard deviation

SOP \#3 - Pearson-r

\section{Presentation, Analysis and Interpretation of Data}

This part of the study contains the graphs and tables that present the data collected from respondents, analysis, and the interpretation of the results attained by the researcher.

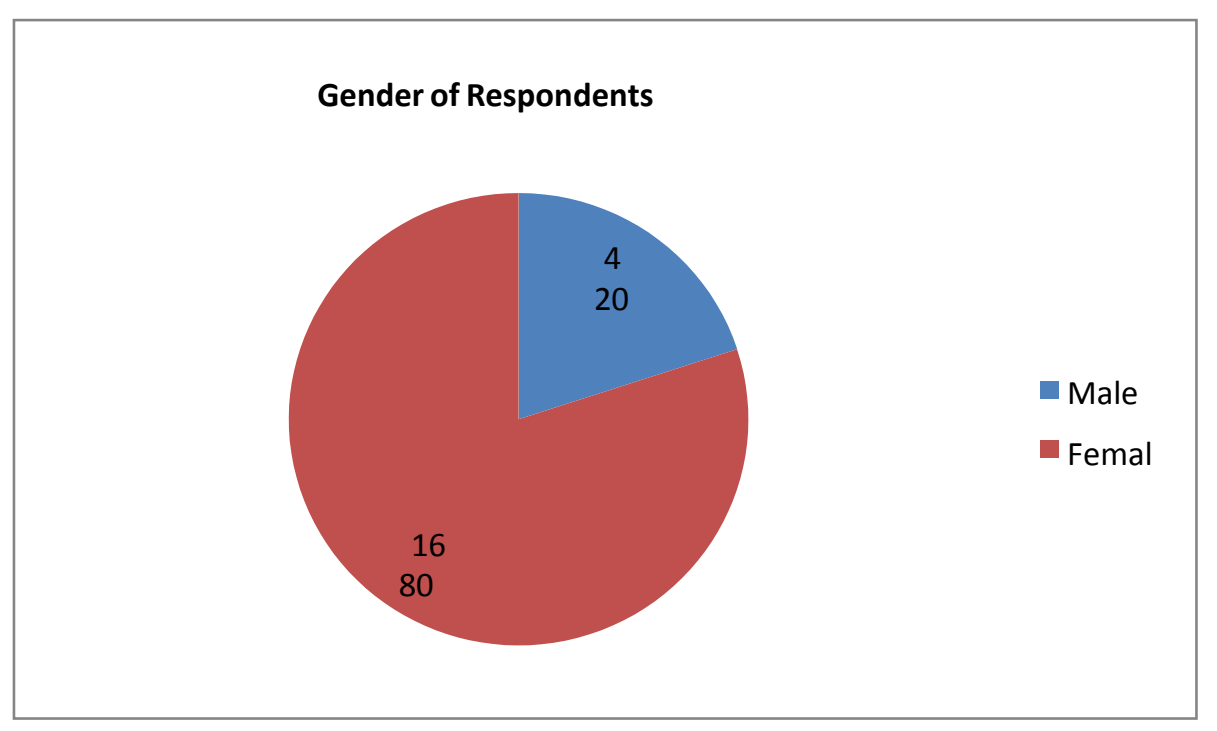

Figure 4. Gender of Respondents

The table above denotes the gender of the respondents. It can be seen that 16 of them are 
female that covers up $80 \%$ of the total number of respondents while 4 of them are male that covers up $20 \%$.

This means that most of the sole proprietorships established inNagcarlan Central Business District have owners who are female and they are dominant in the business industry in our town nowadays.

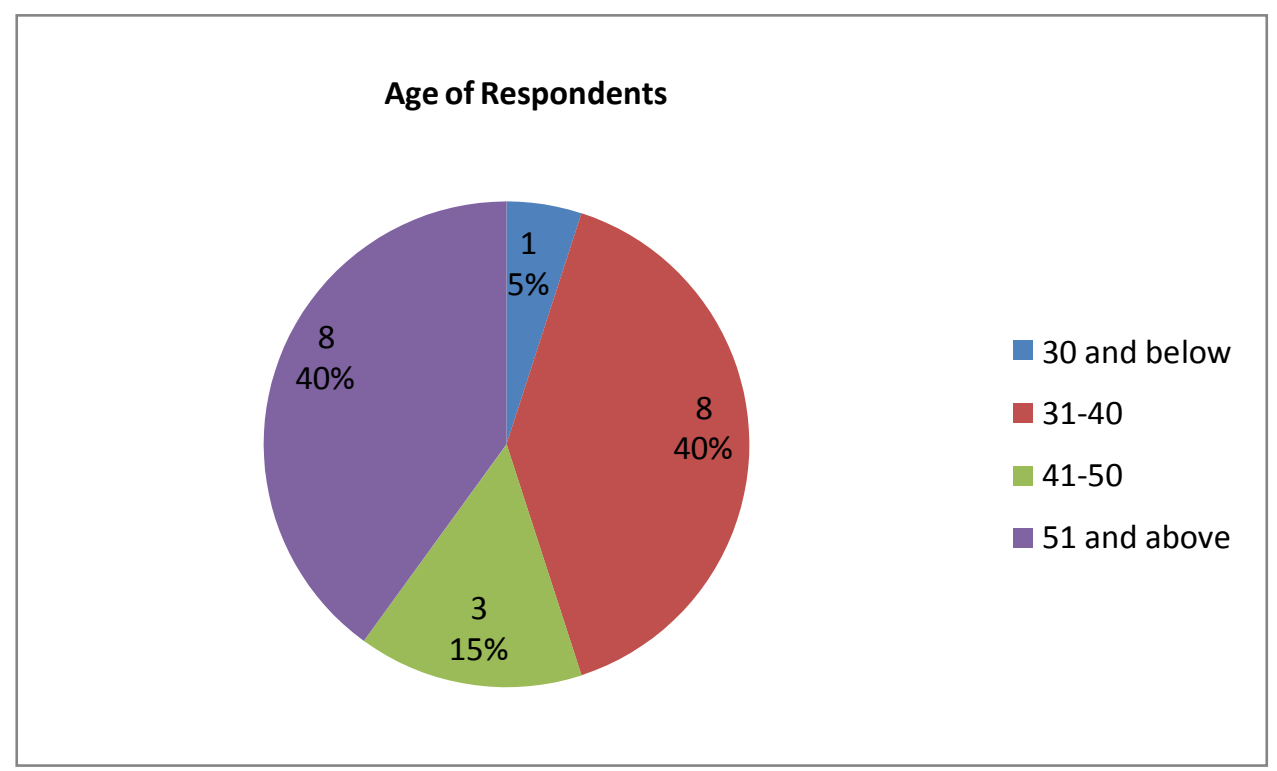

Figure 5. Age of Respondents

The graph above depicts the age of the respondents. It can be seen that 8 respondents have an age of 51 and above that covers up $40 \%$ of the total number of respondents in the study. Also, 8 of themhave an age of 31-40 that covers up 40\%, 3 have an age of 41-50 that covers up $15 \%$, and only 1 has an age of 30 and below that covers up 5\%.

This means that most of the sole proprietorships established in Nagcarlan Central Business District have owners who are above 30 years of age and in the stage of life wherein they are managing their own businesses or jobs stably.

Table 1. Mean Level of the Taxpaying Benefits Satisfaction

\begin{tabular}{|l|c|c|c|}
\hline \multicolumn{1}{|c|}{ Indicators } & Mean & SD & Interpretation \\
\hline $\begin{array}{l}\text { 1. I see the improvement of public roads in } \\
\text { Nagcarlan. }\end{array}$ & 3.9 & 0.85 & $\begin{array}{c}\text { High Level of } \\
\text { Satisfaction }\end{array}$ \\
\hline 2. I feel the enhancement of water systemin our town. & 3.15 & 1.09 & $\begin{array}{c}\text { Moderate } \\
\text { Level of } \\
\text { Satisfaction }\end{array}$ \\
\hline 3. I am thankful for the free check-ups inpublic hospitals. & 3.75 & 1.12 & $\begin{array}{c}\text { High Level of } \\
\text { Satisfaction }\end{array}$ \\
\hline
\end{tabular}




\begin{tabular}{|l|c|c|c|}
\hline $\begin{array}{l}\text { 4. Free tuition fees in public schools make } \\
\text { me happy. }\end{array}$ & 4.1 & 1.37 & $\begin{array}{c}\text { High Level of } \\
\text { Satisfaction }\end{array}$ \\
\hline $\begin{array}{l}\text { 5. I am happy that more educational books } \\
\text { are being given to public schools in ourtown. }\end{array}$ & 3.55 & 1.28 & $\begin{array}{l}\text { High Level of } \\
\text { Satisfaction }\end{array}$ \\
\hline $\begin{array}{l}\text { 6. I am aware with the addition of new classrooms in } \\
\text { public schools in Nagcarlan. }\end{array}$ & 4.05 & 1 & $\begin{array}{l}\text { High Level of } \\
\text { Satisfaction } \\
\text { Moderate } \\
\text { Level of } \\
\text { Satisfaction }\end{array}$ \\
\hline $\begin{array}{l}\text { 7. I feel safe and secured because of theprotection given by the } \\
\text { police in our town. }\end{array}$ & 3.4 & 0.88 & $\begin{array}{l}\text { High Level of } \\
\text { Satisfaction } \\
\text { Moderate } \\
\text { Level of } \\
\text { families living in Nagcarlan. }\end{array}$ \\
\hline $\begin{array}{l}\text { 9. I receive quick help from the governmentwhenever there is } \\
\text { a natural disaster (e. g. typhoons, earthquakes, and volcanic } \\
\text { eruptions) that affected my business. }\end{array}$ & 3.15 & 1.09 & 0.76 \\
\hline $\begin{array}{l}\text { Satisfaction } \\
\text { Security Program inour country that provides benefits to } \\
\text { people in incidents like sickness, maternity, } \\
\text { disability, retirement, and death. }\end{array}$ & 4.05 & 0.89 & $\begin{array}{l}\text { High Level of } \\
\text { Satisfaction }\end{array}$ \\
\hline AVERAGE & 3.66 & 1.03 & $\begin{array}{l}\text { High Level of } \\
\text { Satisfaction }\end{array}$ \\
\hline
\end{tabular}

\section{Legend:}

4.21-5.00

3.41-4.20

2.61-3.40

$1.81-2.60$

$1.00-1.80$

\author{
Very High Level of Satisfaction \\ High Level of Satisfaction \\ Moderate Level of Satisfaction \\ Low Level of Satisfaction \\ Very Low Level of Satisfaction
}

The table above shows the mean level of taxpaying benefits. Tenquestions about the taxpaying benefits were answered by the respondents on the questionnaire survey. The results of this process were recordedand statistically treated. Questions No. 1, 2, 3, 4, 5, 6, 7, 8, 9, and 10 gained means of $3.9,3,15,3.75,4.1,3.55,4.05,3.4,3.5,3.15$, and 4.05, respectively, and standard deviations of $0.85,1.09,1.12,1.37,1.28,1,0.88,0.76,1.09$, and 0.89 , respectively.

The indicator that got the highest mean of 4.1 is Question No. 4, showing that the respondents are in a high level of satisfaction on the free tuition fees in public schools. This means that sole proprietors in Nagcarlan Central Business District are satisfied with the free and accessible education for all people especially those living in our town. While Questions No. 2 and 9 both obtained the lowest mean of 3.15, signifying that the respondents are in a moderate level of satisfaction on the enhancement of water system in our town and on the quick help from the government whenever there is a natural disaster that may affect their business, respectively. This means that sole proprietors are somewhat satisfied with how the water system in our town is managed and propagated by the municipal government. Furthermore, neither of the respondents experienced a very high 
nor a very low level of satisfaction on any indicators above.

Table 2. Mean Level of the Business Performance

\begin{tabular}{|c|c|c|c|}
\hline Indicators & Mean & SD & Interpretation \\
\hline $\begin{array}{l}\text { 1. My business earns good amount of } \\
\text { income. }\end{array}$ & 3.65 & 0.75 & $\begin{array}{l}\text { High Level of } \\
\text { Performance }\end{array}$ \\
\hline 2. My business is competitive in the market. & 3.75 & 0.85 & $\begin{array}{l}\text { High Level of } \\
\text { Performance }\end{array}$ \\
\hline 3. My business does not have many debts. & 3.65 & 0.93 & $\begin{array}{l}\text { High Level of } \\
\text { Performance }\end{array}$ \\
\hline 4. I have many customers every businessday. & 3.6 & 0.82 & $\begin{array}{c}\text { High Level of } \\
\text { Performance }\end{array}$ \\
\hline $\begin{array}{l}\text { 5. I satisfy the needs of my customers withthe } \\
\text { products/services I am offering in my } \\
\text { business. }\end{array}$ & 4.2 & 0.77 & $\begin{array}{l}\text { High Level of } \\
\text { Performance }\end{array}$ \\
\hline 6. I am operating my business efficientlyand effectively. & 4.35 & 0.67 & $\begin{array}{l}\text { Very High } \\
\text { Level of } \\
\text { Performance }\end{array}$ \\
\hline $\begin{array}{l}\text { 7. I exert quality time and efforts in everypart of my } \\
\text { business. }\end{array}$ & 4.4 & 0.6 & $\begin{array}{l}\text { Very HighLevel } \\
\text { of } \\
\text { Performance }\end{array}$ \\
\hline 8. I am motivated to manage my businesssuccessfully. & 4.45 & 0.6 & $\begin{array}{l}\text { Very High } \\
\text { Level of } \\
\text { Performance }\end{array}$ \\
\hline 9. I am achieving the goals I prepared formy business. & 4.2 & 0.83 & $\begin{array}{l}\text { High Level of } \\
\text { Performance }\end{array}$ \\
\hline 10. I always strive for the best in mybusiness. & 4.65 & 0.59 & $\begin{array}{l}\text { Very HighLevel } \\
\text { of } \\
\text { Performance }\end{array}$ \\
\hline AVERAGE & 4.09 & 0.74 & $\begin{array}{l}\text { High Level of } \\
\text { Performance }\end{array}$ \\
\hline
\end{tabular}

\section{Legend:}

4.21-5.00 Very High Level of Performance

$3.41-4.20$

2.61-3.40

$1.81-2.60$

$1.00-1.80$
Moderate Level of Performance

Low Level of Performance

Very Low Level of Performance

The table above shows the mean level of performance of sole proprietorships in Nagcarlan Central Business District. Ten questions about the performance of sole proprietorships were answered by the respondents on the questionnaire survey. The results of this process were recordedand statistically treated. Questions No. 1, 2, 3, 4, 5, 6, 7, 8, 9, and 10 gained means of 3.65, 3.75, 3.65, 3.6, $4.2,4.35,4.4,4.45,4.2$, and 4.65, respectively, and standard deviations of $0.75,0.85,0.93,0.82$, 
$0.77,0.67,0.6,0.6,0.83$, and 0.59 , respectively.

The indicator that got the highest mean of 4.65 is Question No. 10, showing that the respondents are in a very high level of performance in terms of always striving for the best in my business. This means that sole proprietors in Nagcarlan Central Business District are really going all-out in their respective businesses to maximize its potential. While Question No. 4 obtained the lowest mean of 3.6, signifying that the respondents are in a high level of performance in terms of having many customers every business day. This means that the quantity of the customers of sole proprietors in Nagcarlan Central Business District differ each business day. Moreover, none of the respondents experienced a very low level of performance on any indicators above. This means that all of them are performing well in their own businesses.

Table 3. Pearson-r Result of the Two Variables

\begin{tabular}{|c|c|c|c|c|c|}
\hline Variables & Mean & SD & r-value & p-value & Decision \\
\hline $\begin{array}{l}\text { Taxpaying Benefits } \\
\text { Satisfaction of Sole } \\
\text { Proprietors }\end{array}$ & 3.66 & 1.03 & \multirow[t]{2}{*}{0.06} & \multirow[t]{2}{*}{0.87} & \multirow[t]{2}{*}{$\begin{array}{l}\text { There is no } \\
\text { significant } \\
\text { relationship }\end{array}$} \\
\hline $\begin{array}{l}\text { Performance of Sole } \\
\text { Proprietorships }\end{array}$ & 4.09 & 0.74 & & & \\
\hline
\end{tabular}

The table above shows the findings of the research regarding the relationship between the taxpaying benefits satisfaction and the business performance of sole proprietors in Nagcarlan Central Business District. The average mean and standard deviation of the independent variable is 3.66 and 1.03, respectively, while the dependent variable is 4.09 and 0.74 , respectively. After using the statistical tool which is Pearson-r, it can be seen that the r-value, 0.06, is very near to 0 .

The result of the statistical treatment shows that there is no significant relationship between the two means. The p-value, 0.87, which is higher than the alpha level of 0.05 , strengthens the claim. Hence, the taxpaying benefits satisfaction does not have a significant relationship with the business performance of sole proprietors in Nagcarlan CentralBusiness District. This means that even though the level of taxpaying benefits satisfaction gets higher or lower, it will not cause the business performance to get higher or lower level also. There may be other external factors that have a relationship with the increasing or decreasing of business performance of sole proprietors in Nagcarlan Central Business District such as unpredictable demand of customers and tough competition in the market.

The result of this study is similar to the result of the study of Ganeshasundaram Raguragavan (2001). Raguragavan concluded in his study that there is no significant relationship between market research and business performance because different types of market research have different effects on business performance.

\section{Summary of Findings, Conclusion and Recommendation}

This section of the paper highlights the summary of findings, conclusion, recommendation, and the reflection of the researcher, as well.

\subsection{Summary of Findings}

The purpose of this study is to determine the relationship between the taxpaying benefits satisfaction of sole proprietors and the performance of their businesses in Nagcarlan Central Business District.

Specifically, this intends to answer the following questions: 
- What is the mean level of the taxpaying benefits satisfaction?

- What is the mean level of the business performance?

- Is there a significant relationship between the taxpaying benefits satisfaction and the business performance of sole proprietors in Nagcarlan Central Business District?

After statistically treating the data gathered, the findings are as follows:

- The mean level of the taxpaying benefits satisfaction is 3.66 and its standard deviation is 1.03 .

- The mean level of the business performance is 4.09 and its standard deviation is 0.74 .

- The r-value is 0.06 , which is very near to 0 .

- The p-value is 0.87 , which is greater than the alpha level of 0.05 .

\subsection{Conclusion}

There is no significant relationship between the taxpaying benefits satisfaction and the business performance of sole proprietors in Nagcarlan Central Business District. This means that an increase or decrease in the taxpaying benefits satisfaction does not corresponds to an increase or decrease in the business performance.

\subsection{Recommendation}

In this part, the following recommendations for the following person, people, or authority are proposed in accordance with the results achieved in this study and the above-mentioned conclusion:

- Government must still be consistent in providing the necessary benefits to its stakeholders especially to sole proprietors that comply to the taxation system even though their businesses have either high or low level of performance in the economy. They should also conduct a seminar for business owners wherein the taxpaying benefits will be thoroughly emphasized and discussed for them tobe well-informed on where do the money they pay to taxes really go.

- Sole proprietors should still perform well in their respective businesses and always be optimistic with the beneficial projects by our government in our community. They should always pay their taxes properly and stand up for their rights if there's something unjust happening in the taxation system.

- Future researchers should conduct studies on what can be the possible factors in the business industry that anything about taxation can relate to. They should also use this research about the relationship between the taxpaying benefits satisfaction of sole proprietors and the performance of their businesses in Nagcarlan Central Business District in supporting their works.

\subsection{Reflection}

The researcher learned that it's not the taxpaying benefits satisfaction of sole proprietors that causes them to increase the performance level of their business. Maybe they are just satisfied with it but that is not their source of motivation to perform well. The researcher thinks that the only objectives of these sole proprietorships to strive for the best are to earn income and to respond to the needs or wants of their customers, not to expect the government to add more benefits in the community.

Going deeper, the researcher learned that making a research paper is really challenging. But just like what Joshua J. Marine said, "Challenges are what make life interesting and overcoming them is 
what makes life meaningful." For me, it doesn't matter how harshly you started. As long as you did your best to correct your mistakes and to finish satisfyingly, you will achieve success. What's more important is the good lesson you've learned that will help you for your personal development.

\section{Acknowledgement}

First and foremost, the researcher wants to express his deep gratitude to his parents, REXIBAL S. PLATA SR. and VIOLETA B. PLATA, for their unwavering support and encouragement when he thought of giving up while facing the challenges. The researcher also wants to acknowledge the principal of our beloved school, MRS. JOSEFA U. ORIJOLA, for her contribution in this research. This project will not be possible without the help and guidance of MR. ELYMAR PASCUAL, our research adviser who shared all of his valuable knowledge about research that really helped for the successfulness of this study. The researcher's classmates who gave advices regarding the topic of this research are acknowledged, as well. And lastly, the researcher wants to acknowledge other authors, editors, and researchers who became the sources of some important information written here.

\section{References}

Bae, J. I. (2006). The Relationship Between Benefit Satisfaction andIntent to Leave: A Study of Finance in Las Vegas. p. iii. http://dx.doi.org/10.34917/2507846

Franklin, B. (1789). Benjamin Franklin's last great quote and the Constitution. https://constitutioncenter.org/blog/benjamin-franklinslast-great-quote-and-the-constitution

Jepkogei, T. C. (2014). Impact of Taxation on the Growth of Small Micro Enterprises: Case Study of Selected SMES in Iten Town. p. 8. https://edoc.tips/download/impact-of-tax-on-small-businesses-edwin-oyaro-edu_pdf

Gale, W. and Samwick, A. (2014). Effects of Income Tax Changes on Economic Growth. p. i. https://www.brookings.edu/wpcontent/uploads/2016/06/09_effects_income_tax_changes_economic_growth_gale_samwick.pdf

Lin, Y. C., Hsing, M. Y., and Wang, Y.C. (2008). Research on Business Strategy and Performance Evaluation in Collaborative Design. p. 11. https://papers.ssrn.com/sol3/papers.cfm?abstract_id=2420157

Lindhe, T., Södersten, J., and Öberg, A. (2003). Economic Effects of Taxing Different Organizational Forms under a Dual Income Tax. p. 1. http://www.diva-portal.org/smash/get/diva2:129273/FULLTEXT01.pdf

Marron, D. (2014). Tax Issues Facing Small Business. p. 1. https://docs.house.gov/meetings/SM/SM00/20140409/101977/HHRG113-SM00-20140409-SD003-U4.pdf

Mungaya, M., Mbwambo, A. H., and Triphati, S. K. (2012). Study ofTax System Impact on the Growth of Small and Medium Enterprises (SMEs): With Reference to Shinyanga Municipality, Tanzania. p. 1. http://www.ijmbs.com/23/mika.p

Raguragavan, G. (2001). The Relationship Between Market Research and Business Performance. p.i. https://mro.massey.ac.nz/bitstream/handle/10179/2067/02_whole.pdf?sequence=1\&isAllowed=y

Shaharuddin, N. S. (2012), Sole Proprietorship and Tax Compliance Intention in Self Assessment System: A Theory of Planned Behavior Approach. International Journal of Business, Economics, and Law, Vol. 1, p. 34. http://ijbel.com/wpcontent/uploads/2014/06/Sole-Proprietorship-And-Tax-Compliance-In-Sas-A-Theory-Of-Planned-Behavior-Approach-NoorSuhaila-Shaharuddin-Mohd-Rizal-Palil-Rosiati-Ramli-Ruhanita-Maelah.pdf

Tee, E., Boadi, L. A. and Opoku, R. T. (2016). The Effect of Tax Payment on the Performance of SMEs: The Case of Selected SMEs in $\mathrm{Ga} \quad$ West $\quad$ Municipal Assembly. $\quad$ p. https://www.researchgate.net/publication/318877876_The_Effect_of_Tax_Payment_on_the_Performance_of_SMEs_The_Ca se_of_Selected_SMEs_in_Ga_West_Municipal_Assembly

Vermonty, S. (1999). Chapter 2: Taxation of a Sole Proprietorship. p. 14.

Wicksell, K. and Lindahl, E. (n. d.). Theories of Taxation. EconomicsConcepts.com

Zulkiffli, S. N. A. and Perera, N. (2011). A Literature Analysis on Business Performance for SMES - Subjective or Objective Measures?.p. 5. https://ro.uow.edu.au/gsbpapers/312/ 